\title{
Prevention of infective endocarditis in dental procedures for tetralogy of fallot patients
}

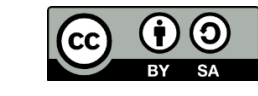
This work is licensed under a
Creative Commons Attribution 4.0 which permits use, distribution and reproduction, provided that the original work is properly cited,
the use is non-commercial and no modifications or adaptations are made.
${ }^{1}$ Department of Pediatric Dentistry, Faculty of Dentistry, Universitas Hang Tuah, Surabaya, Indonesia 60111

*Correspondence to:

Ari Rosita Irmawati

凶ari.irmawati@hangtuah.ac.id

Received on: May 2021 Revised on: July 2021

Accepted on: August 2021

\author{
Ari Rosita Irmawati ${ }^{*}$, Ayulistya Paramita Sutarto
}

\begin{abstract}
Objectives: Tetralogy of Fallot (ToF) is a congenital heart defect that is often found in children. Complication that can occur is infective endocarditis caused by bacteria that are often found in the oral cavity. Children with ToF are in a high risk of caries, especially in primary dentition. Preparation of the oral cavity must be done before the cardiac surgery. A proper examination and diagnosis of caries is required in determining the dental treatment to reduce the risk of infective endocarditis.
\end{abstract}

Case Report: A boy aged 4 years, weighing $20 \mathrm{~kg}$ came to the pediatric dentistry clinic in Surabaya on a referral from Kediri. The patient had ToF with high caries index and will undergo cardiac corrective surgery. Through a brief anamnesis it was found that this patient's fingernails and lips easily turn blue (cyanosis) if the patient is in an anxious condition. The panoramic photo shows teeth 51,52 , $54,61,62,74,84$ showing radiolucent images from the enamel to the pulp chamber.

Conclusion: Prophylactic antibiotics should be given to ToF patient before procedures involving the gingiva and pulp. Radiographs are needed to help establish the diagnosis and plan treatment. Proper oral and dental care must be taken to prevent the occurrence of infective endocarditis. Errors in determining the diagnosis can lead to errors in the treatment plan and increase the risk of infective endocarditis.

Keywords: Tetralogy of Fallot, endocarditis, dental procedure

Cite this article: Irmawati AR, Sutarto AP. Prevention of infective endocarditis in dental procedures for tetralogy of fallot patients. Jurnal Radiologi Dentomaksilofasial Indonesia 2021;5(2)66-9. https://doi.org/10.32793/jrdi.v5i2.706

\section{INTRODUCTION}

Tetralogy of Fallot (ToF) adalah salah satu penyakit jantung bawaan biru (sianosis) yang memiliki 4 gejala khas, yaitu ventrikel septum defek, stenosis pulmonal infundibular, overriding aorta dan hipertrofi ventrikel kanan. ${ }^{1,2}$ Salah satu gejala yang sering terlihat pada kasus ToF yaitu jari kuku dan bibir yang dapat berubah menjadi biru/ sianosis jika anak mengalami kelelahan akibat aktivitas fisik yang berat, kecemasan yang tinggi, menangis cukup lama. Hal ini dapat membahayakan, karena dapat mengakibatkan kelumpuhan bahkan kematian. $^{3}$

Anak dengan ToF harus segera mendapatkan penanganan untuk menutup defek pada ventrikel. Adanya lubang pada septum ventrikel mengakibatkan terjadinya aliran dari ventrikel kiri ke ventrikel kanan. Jika lubangnya cukup besar dapat menimbulkan keluhan seperti kesulitan waktu makan dan minum, mudah lelah, dan juga dapat menghambat pertumbuhan.

Komplikasi endokarditis juga harus diwaspadai pada kasus penyakit jantung bawaan. Endokarditis adalah penyakit yang disebabkan oleh bakteri seperti streptokokus sanguinis, dan streptokokus mitis yang berhubungan erat dengan infeksi gigi. Pemeriksaan dan penentuan rencana perawatan pada bidang kedokteran gigi perlu diperlukan untuk mencegah terjadinya endokarditis yang disebabkan oleh bakteri. ${ }^{4}$

Pada kasus anak dengan ToF, sebelum dilakukan operasi korektif pada jantungnya, diperlukan persiapan pada rongga mulut yang tepat dengan mempertimbangkan resiko terjadinya endocarditis. Gigi dengan karies dapat menjadi fokal infeksi terjadinya endocarditis infektif.

\section{CASE REPORT}

Seorang anak laki-laki usia 4 tahun, berat badan $20 \mathrm{~kg}$, datang bersama ibunya ke poli spesialis gigi anak di Surabaya atas rujukan dari puskesmas Kediri. Pasien diketahui akan segera dilakukan operasi jantung di Jakarta. Sebelum dilakukan operasi jantung, dokter jantung meminta untuk dilakukan persiapan pada rongga mulut terlebih dahulu. Keluarga pasien memilih dilakukan persiapan pada rongga mulut di Surabaya karena pertimbangan jarak yang lebih dekat. Pasien didiagnosis menderita ToF disertai sianosis. Dari hasil anamnesis diketahui bahwa jari-jari kuku dan bibir pasien seringkali menjadi biru jika kelelahan 
atau menangis cukup lama. Pemeriksaan radiografi thorax (Gambar 1), didapatkan gambaran ukuran jantung terkesan membesar, apeks membulat dan pinggang jantung melurus, gambaran pulmo tidak spesifik dan tidak tampak infiltrat. Sinus phrenicocostalis kanan/kiri tajam dan tulang kosta, clavikula dan scapula normal. Berdasarkan hasi pemeriksaan thorax foto non kontras, dapat disimpulkan terdapat cardiomegali dengan kesan ventrikular septal defek.

Pasien sering mengeluhkan sakit gigi pada rahang atas depan dan juga rahang bawah kanan dan kiri hingga pasien menangis dan susah tidur. Pemeriksaan intra oral didapatkan gigi 51, 52, 54 $61,62,74,84$ karies profunda. Pasien diberi rujukan untuk foto panoramik. Pemeriksaan panoramik radiografi (Gambar 2) dan klinis (Gambar 3) terlihat gigi 51, 52, 54, 61, 62, 74, 84 dengan diagnosis pulpitis irreversible sehingga memerlukan tindakan pencabutan gigi supaya tidak menjadi fokal infeksi saat dilakukan operasi jantung.

Pasien dikonsultasikan ke dokter jantung anak untuk persiapan pencabutan gigi. Setelah mendapat jawaban dari dokter jantung anak, pasien dikonsultasikan ke dokter anastesi. Dokter anastes menyetujui bahwa pasien dapat dilakukan tindakan persiapan rongga mulut dengan general anastesi.

Pasien direncanakan untuk dilakukan tindakan gigi dengan pembiusan umum (general anaesthesia). Pasien diinstruksikan untuk menghentikan obat aspirin 7 hari sebelum tindakan dan masuk rumah sakit satu hari sebelum dilakukan tindakan pencabutan gigi. Dokter anastesi dan dokter jantung anak ikut memeriksa kondisi pasien. Sebelum tindakan juga dilakukan pemeriksaan laboratorium seperti pemeriksaan darah lengkap, bleeding time, clotting time dan hemoglobin. Dokter anastesi berperan dalam menentukan status fisik pasien serta teknik anastesi yang akan digunakan.

Pasien diinstruksikan untuk tidak makan dan minum 6 jam sebelum dilakukan tindakan Pemberian antibiotik profilaksis diberikan 45 menit sebelum tindakan berupa amoksisilin $1000 \mathrm{mg}$, kemudian pasien dibawa ke ruang operasi dan dilakukan tindakan anastesi. Asepsis ekstra ora dilakukan dengan povidone iodin dan alkohol, kemudian pasien ditutup dengan duk steril, kecual pada daerah operasi. Pemberian oropharynx pack dilakukan dan pasien siap untuk dilakukan operasi. Alat yang menempel di badan pasien meliputi alat ECG, pengukur saturasi oksigen dan thermometer untuk memantau suhu tubuh.

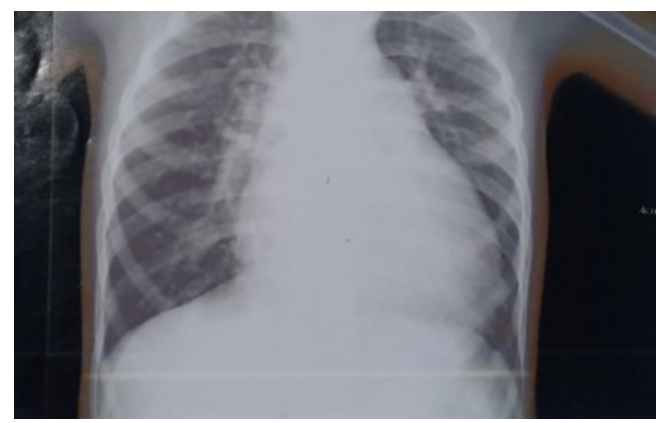

Dokter gigi melakukan asepsis daerah ekstra oral dengan Savlon ${ }^{\mathrm{rm}}$ dan intra oral dengan Betadine ${ }^{\circledR}$ cair. Pasien dipasang mouth spreader dan dilakukan pemeriksaan gigi. Gigi 51, 52, 54, 61, $62,74,84$ dengan diagnosis pulpitis irreversible dilakukan pencabutan dan penjahitan pada soket gigi dengan cath gut (Gambar 4 dan 5). Kemudian dibersihkan dengan larutan $\mathrm{NaCL}$ dan povidone iodin, dilakukan pengambilan kasa di oropharynx. Tindakan ini memerlukan waktu sekitar 2 jam. Pasien dibawa ke ruang pulih sadar, tidak ada komplikasi yang terjadi pasca operasi. Pasien kemudian diinstruksikan untuk meminum obat amoksisilin $3 \times 250 \mathrm{mg}$ selama 3 hari. Keesokan harinya pasien sudah dapat makan dan minum dengan baik sehingga diperbolehkan untuk pulang.

\section{DISCUSSION}

ToF adalah penyakit jantung bawaan yang sering terjadi pada anak. ToF memiliki 4 gejala khas, yaitu ventrikel septum defek, stenosis pulmonal infundibular, overriding aorta dan hipertrofi ventrikel kanan. Insiden terjadinya Congenital Heart Disease adalah 8 dari 1000 kelahiran. Kasus ToF ini terjadi pada $0.26-0.48 \%$ tiap 1000 kelahiran. $^{6}$

Pada kasus di atas, pasien dirujuk untuk dilakukan persiapan pada rongga mulut, sebelum dilakukan operasi jantung untuk koreksi ToF. Gigi dengan diagnosis pulpitis, nekrosis pulpa, sisa akar, harus dilakukan pencabutan, supaya tidak menjadi sumber infeksi terjadinya endokarditis infektif. Kesehatan gigi yang buruk diketahui berhubungan dengan infeksi Streptococcus viridans yang dapat menyebabkan terjadinya endokarditis infektif. ${ }^{4}$ Kondisi rongga mulut yang kebersihannya jelek, karies yang tidak terkontrol sering ditemukan pada pasien ToF yang disertai ventrikular septal defek ${ }^{7}$

Endokarditis infektif adalah infeksi bakteri pada permukaan endokardium jantung. ${ }^{8}$ Faktor yang berperan terjadinya endokarditis infektif adalah masuknya bakteri ke dalam aliran darah, keadaan ini dapat lebih parah pada pasien dengan penyakit jantung bawaan yang mengalami kelainan pada katup jantung. ${ }^{9}$ Antibiotik profilaksis digunakan untuk mengurangi resiko terjadinya endokarditis infektif. $^{10}$ Amoksisilin 1000 mg diberikan 45 menit sebelum tindakan operasi gigi. Hal ini sesuai dengan panduan dari Habib G, 2015, Tentang Antibiotik profilaksis prosedur dental invasif pada pasien dengan resiko tinggi (Tabel 1 ).

Gambar 1. Foto thorax non kontras. gambaran ukuran jantung terkesan membesar, apeks membulat dan pinggang jantung melurus, gambaran pulmo tidak spesifik dan tidak tampak infiltrat. Sinus phrenicocostalis kanan/kiri tajam dan tulang kosta, clavikula, scapula normal. 


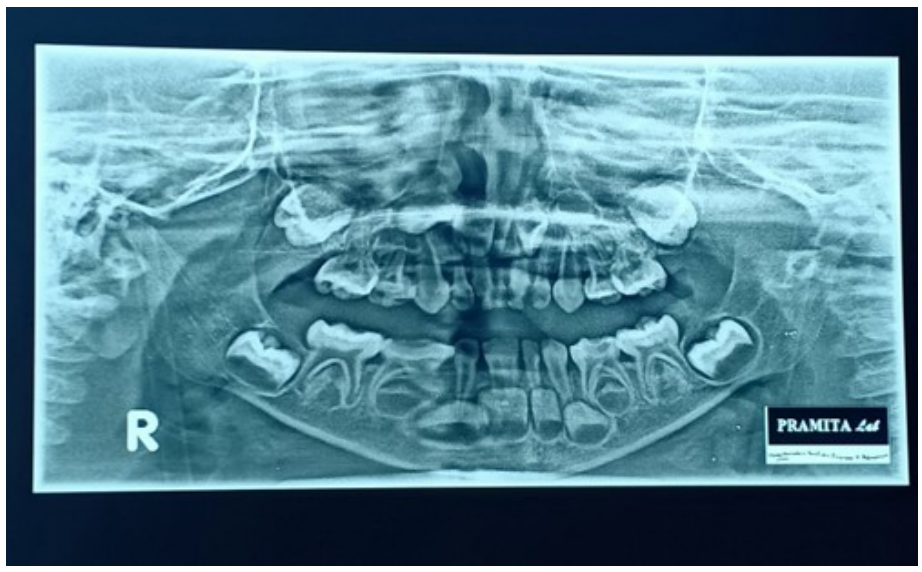

Gambar 2. Foto panoramik tampak gambaran radiolusen mengenai pulpa dari enamel hingga ruang pulpa pada gigi $51,52,54,61,62,74,84$.
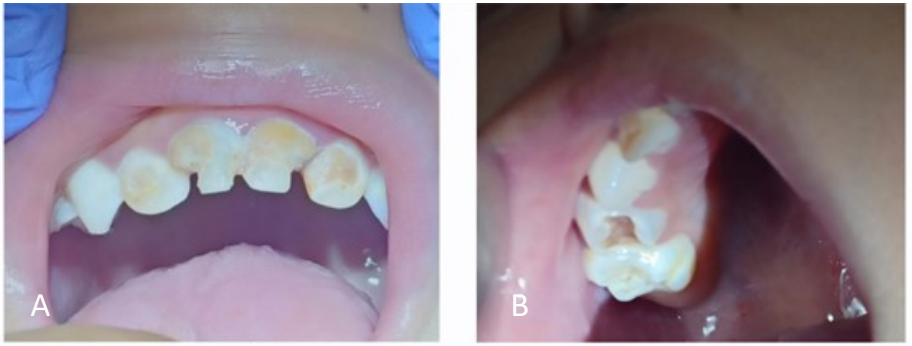

Gambar 3. Tampak kondisi klinis gigi pasien sebelum tindakan. (A) gigi anterior); (B) gigi posterior rahang atas.
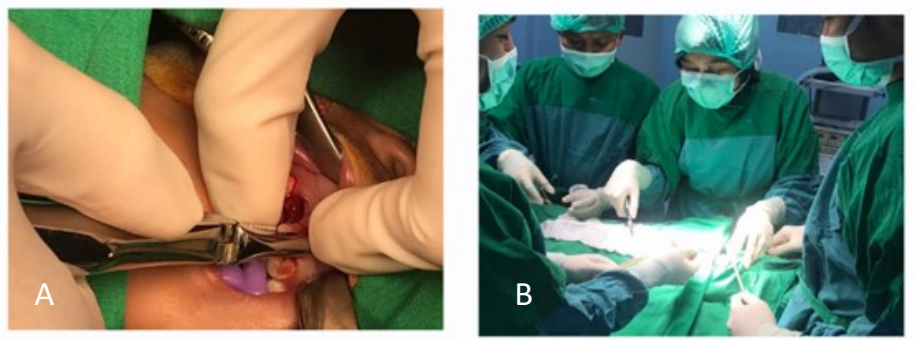

Gambar 4. Tindakan ekstraksi (A) dilakukan dalam kondisi pasien diberikan bius total/general anaesthesia (B).
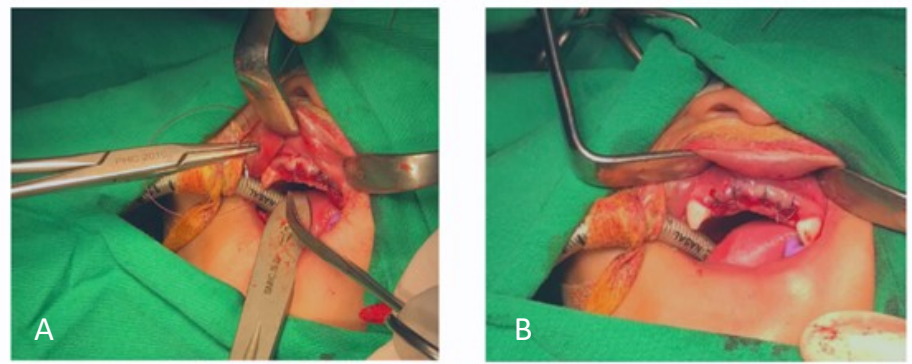

Gambar 5. Tampak kondisi pasien saat dilakukan (A) suturing. dan (B) setelah selesai tindakan.

Penyakit jantung bawaan terbagi menjadi dua, yaitu penyakit jantung bawaan dengan sianotik dan penyakit jantung bawaan asianotik. Pada pasien penyakit jantung sianotik, terjadi penurunan kadar oksigen, sehingga pasien terlihat menjadi biru. Serangan sianotik ditandai dengan napas yang lebih cepat dan dalam, timbulnya sesak napas mendadak dan dapat mengakibatkan kejang atau sinkop. Kondisi hipoksia yang terlalu lama dapat merusak sel sel otak serta mengakibatkan kematian. Faktor terjadinya kondisi sianotik ini antara lain adalah kelelahan, kecemasan, aktifitas fisik yang berat, demam. ${ }^{3}$ Kondisi sianosis bisa tidak tampak sejak lahir. Jika ductus arteriosis masih terbuka dan darah dapat masuk ke dalam paru,tidak akan terjadi sianosis. Jika celah pada ductus arteriosis menutup sejak awal kelahiran, kemungkinan akan terjadi

\section{sianosis sejak dini. ${ }^{11}$}

Kondisi rongga mulut pada anak dengan ToF memiliki xerostomia, oral hygiene yang buruk. ${ }^{12}$ Kondisi ini disebabkan oleh obat yang rutin dikonsumsi. Keadaan ini meningkatkan resiko terjadinya karies dan penyakit periodontal. Tindakan pencegahan seperti pemberian lapisan pada fisura gigi dan topikal aplikasi fluoride dapat diberikan untuk mencegah keparahan karies.

Diagnosis yang tepat diperlukan untuk menentukan rencana perawatan. Untuk mendiagnosis karies gigi, tidak dapat dilakukan hanya dengan pemeriksaan klinis saja. ${ }^{13}$ Diperlukan pemeriksaan penunjang radiografi untuk menentukan kedalaman karies, bentuk akar, melihat ada atau tidaknya kista, keganasan jaringan lunak. ${ }^{13}$ Karies yang belum mengenai pulpa dapat 
Tabel 1. Antibiotik profilaksis yang digunakan dalam prosedur dental invasif pada pasien dengan risiko tinggi

\begin{tabular}{llll}
\hline Kondisi Pasien & Antibiotik & Dewasa & Anak \\
\hline Tidak alergi penisilin/ ampisilin & Amoksisilin/ ampisilin & $2 \mathrm{gr}$ Per Oral /IV & $50 \mathrm{mg} / \mathrm{kg} /$ Per Oral / IV \\
Alergi penisilin/ ampisilin & Klindamisin & $600 \mathrm{mg}$ per oral / IV & $20 \mathrm{mg} / \mathrm{kg} / \mathrm{PO} / \mathrm{IV}$ \\
\hline
\end{tabular}

Keterangan: diberikan dosis tunggal 30-60 menit sebelum tindakan

dilakukan tumpatan dengan semen ionomer kaca. Karies yang sudah mengenai pulpa, tidak dapat dilakukan perawatan saluran akar dan harus dicabut. ${ }^{5}$ Hal ini disebabkan karena gigi tersebut dapat menjadi fokal infeksi terjadinya endokarditis infektif. Dengan metode tertentu, foto radiograf panoramik dapat digunakan untuk menentukan usia biologis yang berguna dalam membantu identifikasi forensik. ${ }^{14}$

Pasien yang akan menjalani operasi jantung untuk korektif ToF, perlu mendapat perawatan $\mathrm{d}$ bidang kedokteran gigi untuk mengurangi resiko terjadinya endokarditis infektif. ${ }^{15}$ Satu dari 8 anak dengan kelainan jantung bawaan, dapat terkena endocarditis infektif setelah dilakukan tindakan pada gigi. ${ }^{16}$ Bakteri penyebab endokarditis infektif, ditemukan pada pasien dengan kondisi kebersihan rongga mulut yang buruk. ${ }^{14} \mathrm{pH}$ saliva, laju kecepatan saliva, kebersihan rongga mulut pada pasien dengan ToF dapat menentukan derajat keparahan karies yang terjadi. ${ }^{17}$

Pada pasien ToF, American Academics of Pediatric Dentistry (AAPD) merekomendasikan pemberian antibiotik pada tindakan gigi yang melibatkan gingiva atau periapikal gigi. Dokter gigi harus memberikan profilaksis antibiotik untuk mengurang resiko terjadinya endokarditis infektif. Tindakan yang tidak memerlukan antibiotik profilaksis yaitu foto radiografi, pemasangan gig palsu serta alat ortodonti lepasan dan cekat. ${ }^{18}$

\section{CONCLUSION}

Antibiotik profilaksis harus diberikan sebelum tindakan yang melibatkan gingiva dan periapikal. Foto radiograf diperlukan untuk membantu menegakkan diagnosa dan rencana perawatan. Perawatan gigi dan mulut yang tepat harus dilakukan untuk mencegah terjadinya endokarditis infektif. Kesalahan dalam penentuan diagnosa dapat menyebabkan kesalahan dalam rencana perawatan sehingga meningkatkan resiko terjadinya endokarditis infektif.

\section{ACKNOWLEDGMENTS}

None.

\section{FOOTNOTES}

All authors have no potential conflict of interest to declare for this article. Informed consent was obtained from the patient for being included in this case report.

\section{REFERENCES}

1. Soebroto H, Akbar E, Hakim AR. Primary repair tetralogy of fallot and major aorto-pulmonary collateral arteries with suspected Noonan syndrome: A rare case. JKKI: Jurnal Kedokteran dan Kesehatan Ind. 2020;11(3):302-8

2. Dabbagh A, Conte AH, Lubun L. Congenital heart disease in pediatric and adult patients: Anesthestic and perioperative management 1st ed. Switzerland: Springer International Publishing; 2017. p.50-4.

3. Rilantono LI, Baras F, Karo SK, Roebiono PS. Buku Ajar Kardiologi. Jakarta: Balai Penerbit Fakultas Kedokteran Universitas Indonesia; 2003.

4. Rushani D, Kaufman JS, lonescu-Ittu R, Mackie AS, Pilote L, Therrien J, Marelli AJ. Infective endocarditis in children with congenital heart disease: cumulative incidence and predictors. Circulation. 2013;128(13):1412-9.

5. Ayala CDL, Aguayo L. Oral and systemic manifestations, and dental management of a pediatric patient with Tetralogy of Fallot. A case report. J Oral Res 2016;5(2): 87-91.

6. Agarwala B. Tetralogy of Fallot. J Cardiol. 2017:1(2):000107.

7. Garrocho-Rangel A, Echavarría-García AC, Rosales-Bérber MA, Flores-Velázquez J, Pozos-Guillén A. Dental management of pediatric patients affected by pulmonary atresia with ventricular septal defect: A scoping review. Med Oral Patol Oral Cir Bucal. 2017;22(4):458-66.

8. Willim HA. Endokarditis Infektif: Diagnosis, Tatalaksana, dan Pencegahan. CDK: Cermin Dunia Kedokteran. 2020;47(8):40712

9. Keynan $Y$, Rubinstein E. Pathophysiology ofinfective endocarditis. Curr Infect Dis Rep. 2013:15(4):342-6.

10. Habib G, Lancellotti $P$, Antunes MJ, Bongiorni MG, Casalta JP, Del Zotti F, et al. 2015 ESC guidelines for the management of infective endocarditis: the task force for the management of infective endocarditis of the European Society of Cardiology (ESC). Eur Heart J. 2015;36(44):3075-128.

11. Gedik S, Gedik R, Gedik TN. Tetralogy of Fallot: Report of 30 Cases and Dental Considerations with Review of Literature. WIMJ Open 2015;2(2):102-5

12. Gupta PV. Pediatric Dentistry for Special Child. New Delhi: Jaypee Brothers Medical Publishers; 2016. p.109-23.

13. Mudjosemedi M, Widyaningrum R, Gracea RS. Perbedaan Hasil Pengukuran Horizontal pada Tulang Mandibula dengan Radiograf Panoramik. Maj Ked Gi Ind. 2015;1(1):78-85.

14. Woroprobosari NR, Utami NR, Hadianto E. Estimation of Biological Ages with Kvaal Method Using Panoramic Radiography in Semarang City. Denta Jurnal Kedokteran Gigi. 2020;14:16-20.

15. Hayes-Lattin M, Salmi D. Educational Case: Tetralogy of Fallot and a Review of the Most Common Forms of Congenital Heart Disease. Acad Pathol. 2020;7:2374289520934094.

16. Hegde AM, Kavita R, Sushma KS, Suchetha S. Salivary sialic acid levels and dental health in children with congenital heart disease. J Clin Pediatr Dent. 2012;36(3):293-6.

17. Chinawa JM, Vijay A, Gaikwad S, Trivedi B, Chukwu B. Clinical profile and surgical outcomes of children presenting with teratology of Fallot. J Cardiol Cardiovasc Med. 2020;5:157-62.

18. American Academy of Pediatric Dentistry. Antibiotic prophylaxis for dental patients at risk for infection. The Reference Manual of Pediatric Dentistry. Chicago, III.: American Academy of Pediatric Dentistry; 2020:447-52. 